\title{
Facilitating Affectively To Increase Learning And Decrease Cheating In The Classroom
}

Bahaudin G. Mujtaba, (Email: mujtaba@nova.edu), Nova Southeastern University Joseph W. Kennedy, (Email: jwk21@cox.net), Edward Waters College

\begin{abstract}
In today's college environment there has been an influx of reports and news concerning student cheating, and dishonesty. This paper informs the reader how to affectively change the venue of learning today, by applying participatory facilitation skills to increase interest and retention with today's students. This was espoused by Benjamin Bloom, through his work utilizing "Bloom's Taxonomy of Learning."
\end{abstract}

\section{INTRODUCTION TO THE WIDESPREAD CHALLENGE OF CHEATING IN SCHOOL}

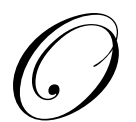

n April $29^{\text {th }}$ 2004, ABC's (American Broadcasting Corporation) Prime Time had a segment on cheating in the education system by students. This was something interesting as they tackled the issue of cheating in colleges and high schools. They found that $75 \%$ of students admitted to cheating on an exam or paper. This Prime Time segment titled "Caught Cheating in School" was a six-month study of college and high school students about cheating practices and the reasons why students cheat. The research, claiming that cheating is at an all time high, was facilitated and narrated by Charlie Gibson (Mujtaba and Preziosi, 2005).

Of the 12,000 college students, $75 \%$ admitted that they have cheated on an exam or term project. According to Mujtaba and Preziosi (2005), these students said that they know cheating is wrong but they do it in order to be better prepared for real life in the business world where cheating and manipulating the system to get ahead seems to be the norm. Students are using calculators, cell phones, computers, and other devices to store and/or download relevant information to complete the exam. Many schools have wireless access to the internet and students are fully able to use this system to download the answers and cheat very easily. One student was timed by Charlie Gibson to see how long it takes her to get the answer for one of the questions from another student using her cell phone's text messaging function. It took her less than 30 seconds, using one hand under table while the other hand seemed to be attempting to take the test, to ask the question and receive the answer. Furthermore, ABC's poll concluded that $36 \%$ of high school students admitted that they had cheated. Furthermore, 7 out of 10 students say that their friends have cheated.

Researchers on the show stated that business administration students are the top cheaters in self reported surveys. They tend to rank first or second amongst the highest cheaters. Some students feel that they need to cheat since their counterparts are doing it. Others feel that they need to cheat as the school system is simply a "dress rehearsal" for the "cut throat" world of business. Many students feel that if senior business officers or religious leaders cheat, and politicians including governors and presidents lie, then they too have the right to cheat and get ahead using tactics available to them. They tend to see the school system as their laboratory for experimentation of tactics used in the real world as senior managers and leaders attempt to manipulate employees, colleagues and other stakeholders for their own personal gain.

Michael Josephson, ethics consultant, stated that students feel as though it is permissible to cheat since professors allow it. There is nothing wrong with the students since they simply think they will get behind if they don't do what they are allowed to do in order to have high performance (Mujtaba and Preziosi, 2005). In a survey of 4,000 American and Canadian school educators, about 50\% stated they have ignored obvious cases of cheating. As such, adults must be aware of cheating methods, stop cheating, teach students that cheating is wrong, and tell them that 
cheaters will be punished. In one case, a college professor found that about a half dozen of his students had cheated from an online site where information was prepared and presented by fifth grade students. It is sad to see that college students do not have time to prepare their own material but rather are plagiarizing from fifth graders. They feel that they have to keep up their grade point average (GPA) since college recruiters tend to hire those with high GPAs. Some students feel they must cheat since there is too much work for them to complete in such a short period of time. However, others thought it is the fault of the teachers for not punishing those who cheat.

During one experiment, students were caught cheating by checking their papers in the "Turnitin.com" website to see how many of the submitted papers were plagiarized. "Turnitin.com" is one tool that many educators use to catch cheaters. It can scan about 15,000 papers submitted by educators every day. "Turnitin.Com" tells the faculty what is copied from other sources and what percentage of each paper is directly copied from these sources. The software marks all copied items in red and underlines them for the faculty. All this can be done in a matter of minutes based on the personal experiences of the authors and many colleagues that regularly use it.

Some students cheat because they don't think that they have the time to do a quality job in order to get a good grade. One student said that the "general student body" feels that cheating is allowed in some cases, especially when one has several assignments that are due on the same day which leaves little to no time to complete them all qualitatively. One of the teachers in the experiment asked her class "How many of them would cheat if they knew that they would not get caught?" Practically all of the students raised their hands. These students were given an assignment after this discussion and about $67 \%$ (two third) of the class had copied much of the material from other sources as their own without proper citation and referencing. In some cases, students had only copied a few phrases as their own while others had copied as much as $80 \%$ of the material despite the fact that these students had seen the Robinson's Honor Code posted everywhere in their school and had a discussion on cheating during the same week. Subsequent discussions with these students showed that they felt cheating on academic assignments were a necessity for high performance and college entry. One high school student who had copied $80 \%$ of the material said he started the paper early in the evening, then ate dinner and finally helped his mother with the dishes before returning to complete the paper. At this time, it was 11:00 PM and he cheated because he did not want to stay up until 3:00 AM to complete the assignment. Another student who had also copied $80 \%$ of the assignment said he did it because he did not care much about this class and chose to spend most of his time studying for other more important subjects since he had several other exams and assignments due on the same day. Such forms of cheating are not limited to high schools or two-year community colleges. Research shows that even top universities have had high rates of self-reported cheating. Michael Josephson said the higher the status of the school (such as Ivy League Schools), the more competitive the environment, the more pressure to earn higher grades, then the higher the rates of cheating will be in such environments. This is also true of the real world where the biggest bankers get caught cheating at the highest rates since the competition is very tough for them to do well (Mujtaba and Preziosi, 2005).

Some students hire a professional writer to write their papers at a cost of approximately $\$ 25$ each. One writer, named Andy, said that he has written over 500 papers thus far for his "clients" who come to him mainly through word-of-mouth advertising. Andy, who sees himself as a business person and an entrepreneur, stated that for a fee he sometimes takes tests for students in classes or for entry exams. For papers, Andy downloads the needed material for his "client's" topic and re-writes each sentence in order to beat "Turnitin.com" and other such software. He feels as though he is helping students earn better grades while earning a regular income for expenditure in society. So, based on Andy's thinking, this is a win-win situation for all involved. Andy also writes applications and essays for students who are trying to get into medical and law schools which tend to have higher enrollment standards than most other schools. In terms of goals Andy, who is currently a student, wants to become a medical doctor. Other students in this discussion also stated that they are going to school to become lawyers, doctors, and senior business officers. However, Charlie Gibson stated that none of them ever mentioned that they are going to school to get an education.

It has now become easier to cheat in college with the availability of carry-on technologies such as calculators, IPAQs, cell phones, and two way pagers. It was extremely easy for the students to cheat through these mediums. One of the students said that, "Cheating in college prepares you for the cut-throat business practices of the real world." They consider it a "dress rehearsal for life." Of-course, many educators are stunned to hear this mindset 
with America's youth. It is not like these are just one in a million. These students figure if they are getting a lower grade when they study, they might as well cheat. They have lost the integrity of actually studying to learn regardless of how much time it takes to understand the concepts. The high school students and college students had the same attitude. The only difference was their motivation: the high school students needed acceptable or competitive grades to get into college and, for many of these students, it didn't matter how they got the grades.

It appalls most educators, to say the least, to know that higher-level students would actually steal words from fifth-graders (Mujtaba and Preziosi, 2005). That doesn't say too much for the educational system, does it? There is another site on the web (www.cheathouse.com) that houses term papers, essays, and book reports for high school and college students. There are several more sites that students seem to come across in assisting them to prepare papers. These sites are such that one can easily buy an essay or report whenever needed. Furthermore, some sites even promise that they have not been plagiarized! It is just a sad state of the world when students place no faith in themselves to do their own research and write their own papers, or they are just too lazy to do it. Perhaps, it just goes to show that many individuals with these upper-level careers do not even belong there if they got ahead using such tactics. It causes one to wonder what ethics is all about. People are reading about business ethics to discover the differences in today's population's values. There seems to be a segment of the population (students or senior officers of large corporations) that will take the low road in every case regardless of the cost or the means. Cheating seems to be similar to a computer virus and worms that mess up programs and hinder productivity. Obviously we are working from a deficit in leaders with character and integrity. How can we change our leaders too?

Back in the old days when most of today's educators went to college there were papers for sale. Some of the campus groups maintained a file for the members to use for various classes. There were people that wrote papers for a price. Yes, there may always be individuals in the population that will try a short cut in every case but their numbers seem to be increasing with the wide usage and availability of cyberspace technology. Technology and the internet can be a good thing and a bad thing in terms of their usage when people do not think about their actions and morals. People have to hold on to their morals and think about that when they are faced with such temptations since these urges for short cuts do not end during one's commencement or graduation. Michael Josephson, founder of the Josephson Institute, was asked about cheating in schools and he said these kids know that it is wrong, but they also think it is the norm. Mr. Josephson has been involved in character education in schools for most of his life and he passionately spoke about these issues in California (Long Beach) as a keynote speaker at the Eighth National Conference on Applied Ethics (sponsored by California State University) where Dr. Bahaudin Mujtaba also presented a paper on ethics in 1997, and where Dr. Joseph W. Kennedy conducted his dissertation research on ethical business practices, utilizing James Rest's Defining Issues Test of Kohlberg's maturity levels. Mr. Josephson was right on target at that time and the problem has only become much more widespread in the past decade. Certainly, educators have to respond to this dilemma and challenge. Almost all schools have some type of a guide that states a "zero tolerance" policy for cheating which basically equates to or is analogous to a corporation's "open door" policy - not having much of an impact. So, more action has to be taken and policies have to be enforced to effectively assess learning and to focus on learning through various means.

While cheating goes on and is becoming part of the norm for some students, there is another dilemma or trend where some students who have great potential are not even going to class or doing homework. Teachers, at times, are not making the necessary inquiries or setting up parent/teacher conferences and the students are suffering. The students know right from wrong and have often taken responsibility for their actions...to a point. However, it is the adult's responsibility to point out to these students their shortcomings. One educator, let's call him Sam, mentioned that "One student that fits this mold is labeled a "troublemaker" by everyone but me. I recognize he has behavior issues in class which seems to be due to the fact he has limited reading skills (this was assessed privately) and he or she is acting out. What a mess and it is getting worse." So, how do schools turn this cheating phenomenon that is becoming a huge problem around before it gets out of hand? Turning this around must start with adults and senior business role models by not cheating stockholders and investors out of their hard earned incomes. These senior officers and political role models must become model citizens by having fair accounting practices and by promoting integrity and honor which are not separate entities from the practice of doing business and getting ahead. Furthermore, as Mahatma Gandhi once stated, "these role models in society must become the change they would like to see in others." 
Most people tend to agree with the solution of the "zero tolerance" policy while modeling expected behaviors and believing that it can work. However, many also believe that it is unlikely to happen on the scale necessary to make a major impact on reducing the level of cheating in schools any time soon. The reasoning stems from witnessing an adult population in schools who have become complacent and let students do almost anything but fight one another in their vicinity. It is as if the attitude is "they are not trying to kill me or each other, so their behavior is ok, and besides I don't need any more hassles." The adults have let the atmosphere deteriorate into this state. So, it is going to be very difficult to rely on them to revive the culture to a new and improved state. Many individuals know we do not have many choices but to rely on adults to lead and children to comply; which might be the best alternative to the current challenge. Administrators, faculty and staff have the power to create and cultivate any atmosphere they "collectively" choose to implement. In some districts, leaders are looked upon with skepticism and distrust where people do not always trust one another wholeheartedly. There is the widespread "us vs. them" mentality reinforcing the dichotomy where people relieve themselves of the responsibility to fix the problem. There are still racial issues and concerns about unfair treatment of minorities and females that educators and employers must overcome as well. There is no "quick fix," no panaceas or easy answers for such complex challenges facing the community. However, most people agree and believe that the adults are just as responsible for the attitudes and behaviors as the students themselves. Once everyone recognizes this responsibility, then there may be hope for all educators, administrators and students on internalizing a commitment for change.

There are hidden issues for some kids that must be considered as the reality of today's life. There are more children today being raised by single parents that have a limited amount of time. Also, today more children and students do not have the benefit of having their extended family members nearby to socialize and interact with them. There is substance abuse on the part of many parents, and students. The children of many substance abusers come to school with limited potential. We have an aging population along with a shortage of qualified teachers entering the profession which leaves the industry with some teachers that are not mentally or physically fit for any level of confrontation. The population is increasing and technology is becoming sophisticated very rapidly where students can keep themselves busy in cyberspace using stimulating games instead of having to listen to monotone lectures about subjects they consider boring. Increased competition, lack of strong values and personal ethics have brought the society to this point where cheating is widespread. The industry is not ready for mass retirements that are going to take place in the next ten years. So, where is the education industry headed in the next few years? Most people claim that education by legislation has not been good for improving the system. Therefore, what is the ethical approach to education?

According to Bloom's research " $95 \%$ of test questions students encounter require them to think only at the lowest possible level to recall the information," which is a common practice in courses today (Mujtaba and Preziosi, 2005). Perhaps, educators need to start using affective facilitation skills to increase learning and decrease cheating. Affective learning today requires instructors to have their students function within an environment that is respectful of their major. A student who is majoring in Business Administration should be expected to operate within a crossfunctional team environment, exhibit affective communication skills, teamwork, and the ability to adapt to a variety of diverse issues within the business world (Colbeck, Campbell, \& Bjorklund 2000).

A study by Shaohua \& Gnyawali, 2003, Synergistic Knowledge Development (SKD) concluded that the use of team based collaborative learning in the classroom increases student performance by embracing practioner based approaches; however, instructors must be able to apply an efficient system in order to manage student conflict, in order to effectively manage student work teams, and to help students be successful with their team-based assignments. According to Bolton (1999), students are not satisfied with team assignments. The authors receive the same reaction from some students; however, they also understand that it is a necessity in order to maximize learning and retention with today's adult students in the classroom. The requirement of diverse assignments and interactions with other team members are not always looked upon positively by students because it requires them to be more involved in the learning process in order to develop higher-order knowledge while improving interaction skills.

Utilizing affective teaching practices in the classroom brings forth holistic learning for the student, which predicates the students' ability to think critically, to evaluate substantive problems, and reflect in ways that integrate the required facets of the students' ability and role within Bloom's Taxonomy of Learning (1956) which develops a 
persons' knowledge and skills at higher levels through affective instruction of analysis, synthesis, and evaluation (Lang \& Dittrich 1982). Bloom's Taxonomy of learning is a hierarchy of six cognitive operations, as can be seen from table 1 (Mujtaba and Preziosi, 2005). The operation at the higher level subsumes all those at the lower levels. Critical thinking according to Bloom answers the questions in regard to each of the following areas (Mujtaba and Kennedy, 2005):

- Knowledge: The lowest level of learning for students and it is a prerequisite for all other steps to follow. This level relies on the students' ability to recall information through memory.

- Comprehension: The student must seek the knowledge and show understanding though collaborative learning, through open structured classroom discussion. Students must explain their reasoning and understanding through case citations or references by what they have read.

- $\quad$ Application: The student applies what they have learned by using examples and comparable analogies. During this step, the instructor must encourage effective facilitation of Collaborative Learning (open structured discussion) in the classroom.

- $\quad$ Analysis: The student must have the ability to distinguish the parts of knowledge applied \& comprehended in the case; thus, the student must be able to discover the underlying structure and hidden meanings and assumptions of the case.

- $\quad$ Synthesis: The student must be able to creatively combine the knowledge obtained during the analysis from several points of view, from the instructor, other students, from the case or other citations. Thus, the students can reassemble component parts into a "New Structure or Thought Process" not previously apparent from the case.

- $\quad$ Evaluation: This is the highest level the student must master in order to think critically and reach. The student must be able to critically appraise the knowledge of the case and apply it within a similar situational factor. Thus, the student must be able to analyze and synthesize business related situations based off of the case method. Students then will make final critical judgments of the case during the Collaborative Learning class session.

The latter steps, in Bloom's Taxonomy, correspond to the highest thinking skills through the steps of analysis, synthesis evaluation (Mujtaba and Preziosi, 2005). The instructor who is facilitating the business ethics topics could encourage and pursue the highest thinking skills for students in each case using Bloom's Taxonomy of Learning. Through effective collaborative learning, on the instructor's part, the student will be more successful in the long-term retention and application of the material (Mujtaba and Kennedy, 2005). Collaborative learning and Bloom's Taxonomy of Learning seek to evaluate and determine the realities of varying businesses by applying ethical standards to specific business scenarios. There are different levels at which people operate during the learning process. Two people may use the same learning tactic, but get very different results. Part of the difference in results may be because of the differences in the level of interactivity between the learner and the learning process. Benjamin Bloom believed in the cognitive learning theory.

Bloom's Taxonomy of Educational Objectives (more commonly known as "Bloom's Taxonomy") is the most popular method of organizing the level at which people operate during the learning process. By utilizing the Taxonomy, one can better judge the level at which s/he is working and the level at which s/he wants to work (Mujtaba and Preziosi, 2005). One can refer to table 1 (Blooms Taxonomy of Learning Levels) to learn the Taxonomy levels, a characteristic of the level, and some action verbs associated with each level. Bloom's Taxonomy can be an extremely valuable set of information. As one proceeds from the knowledge level to the evaluation level, the complexity of the work increases. If people utilize the Taxonomy levels when they are "doing" or learning (activities, exercises, using learning tactics), they will have an understanding of the level at which they are working. Realizing one's level of interactivity can help a person to stay focused on the task at hand. For example, when asking questions and using the self-questioning learning tactic, people don't want to limit themselves to only the lower levels (knowledge, comprehension). It is best to be in the higher levels so that one can get the most out of the experience. 
Table 1 - Bloom's Taxonomy of Learning Levels

\begin{tabular}{|c|c|c|c|c|}
\hline Level & Level Characteristics & \multicolumn{3}{|c|}{ Action Verbs } \\
\hline Knowledge & $\begin{array}{ll}- & \text { specific } \\
\text { - } & \text { ways and means for dealing with } \\
\text { specifics } \\
\text { - } \\
\text { remembering previously learned } \\
\text { facts }\end{array}$ & $\begin{array}{l}\text { cite } \\
\text { label } \\
\text { name } \\
\text { reproduce }\end{array}$ & $\begin{array}{l}\text { define } \\
\text { list } \\
\text { recall } \\
\text { select }\end{array}$ & $\begin{array}{l}\text { Identify } \\
\text { match } \\
\text { recognize } \\
\text { state }\end{array}$ \\
\hline Comprehension & $\begin{array}{ll}\text { - } & \text { translation } \\
\text { - } & \text { interpretation } \\
\text { - } & \text { extrapolation } \\
& \text { meaning of information }\end{array}$ & $\begin{array}{l}\text { convert } \\
\text { describe } \\
\text { estimate } \\
\text { explain }\end{array}$ & $\begin{array}{l}\text { extend } \\
\text { examples } \\
\text { illustrate } \\
\text { interpret }\end{array}$ & $\begin{array}{l}\text { paraphrase } \\
\text { summarize } \\
\text { translate }\end{array}$ \\
\hline Application & $\begin{array}{ll} & \text { using abstractions } \\
\text { - } & \text { using previously learned } \\
\text { information in new and concrete } \\
\text { situations }\end{array}$ & $\begin{array}{l}\text { apply } \\
\text { compute } \\
\text { construct } \\
\text { discover }\end{array}$ & $\begin{array}{l}\text { modify } \\
\text { operate } \\
\text { predict } \\
\text { prepare }\end{array}$ & $\begin{array}{l}\text { Relate } \\
\text { show } \\
\text { solve } \\
\text { use }\end{array}$ \\
\hline Analysis & $\begin{array}{ll}- & \text { breaking a whole into its parts } \\
\text { - } & \text { relationships and organization of } \\
& \text { parts to the whole }\end{array}$ & $\begin{array}{c}\text { analyze } \\
\text { associate }\end{array}$ & $\begin{array}{c}\text { infer } \\
\text { outline }\end{array}$ & point out \\
\hline Synthesis & $\begin{array}{ll} & \text { putting the parts together in a } \\
\text { new form } \\
\text { - } & \text { plan for operation } \\
\text { - unique communication }\end{array}$ & $\begin{array}{l}\text { combine } \\
\text { compile } \\
\text { compose } \\
\text { create } \\
\text { design } \\
\text { develop }\end{array}$ & $\begin{array}{l}\text { devise } \\
\text { iterate } \\
\text { modify } \\
\text { organize } \\
\text { plan } \\
\text { propose }\end{array}$ & $\begin{array}{l}\text { rearrange } \\
\text { reorganize } \\
\text { revise } \\
\text { tell } \\
\text { write }\end{array}$ \\
\hline Evaluation & $\begin{array}{ll}- & \text { making judgments } \\
\text { - } & \text { evidence of logical consistency } \\
\text { - } & \text { ability to make decisions }\end{array}$ & $\begin{array}{l}\text { appraise } \\
\text { assess } \\
\text { compare }\end{array}$ & $\begin{array}{l}\text { Conclude } \\
\text { contrast } \\
\text { evaluate }\end{array}$ & $\begin{array}{l}\text { judge } \\
\text { weigh }\end{array}$ \\
\hline
\end{tabular}

\section{AFFECTIVE FACILITATION: AN EFFECTIVE METHOD OF TEACHING}

The basis of affective facilitation and teaching philosophy presumes a continuous, working relationship between the professor and student (Mujtaba and Kennedy, 2005 \& Mujtaba and Preziosi, 2005). The authors use a variety of teaching strategies in all classes, including small group problem solving techniques, group discussions, case analyses, and team assignments to provide a significant insight for the course. Furthermore, the authors use technology as a catalyst to bridge the business philosophies as an instrument in the learning process, and to provide students with a three-tier system of learning. The three-tier system of learning (refer to Figure 1) provides students' with a repetitive learning environment, which culminates the students' interests by their participation (Bloom's Taxonomy, 2004).

- Lecture Process: Applying theoretical constructs and frameworks for the students. For example, the philosophy and theories of Adam Smith, Frederick W. Taylor and Abraham Maslow would be discussed in the Principles of Management course; thus providing students with a foundation of historical and modern theory in management.

- Visual Aid Technology: Electronic computer based software, such as, Microsoft Office: MS Power-point, MS Word, Internet and E-mail to assist students with their academic pursuits. As the student receives the lecture content, he/she will visually review the material using technology to enhance their learning and retention.

- Class Discussion: The classroom discussion phase with the students concerns the topics of the course lecture material to bridge the theoretical to the applied aspects for the course. The other areas for class discussion are assignments, research paper assignments and mechanics, and any other topic relevant for the course. The classroom discussion phase is one of the most important aspects of adult education. 
Figure 1: Three Tier System of Learning: Multiple Learning Techniques

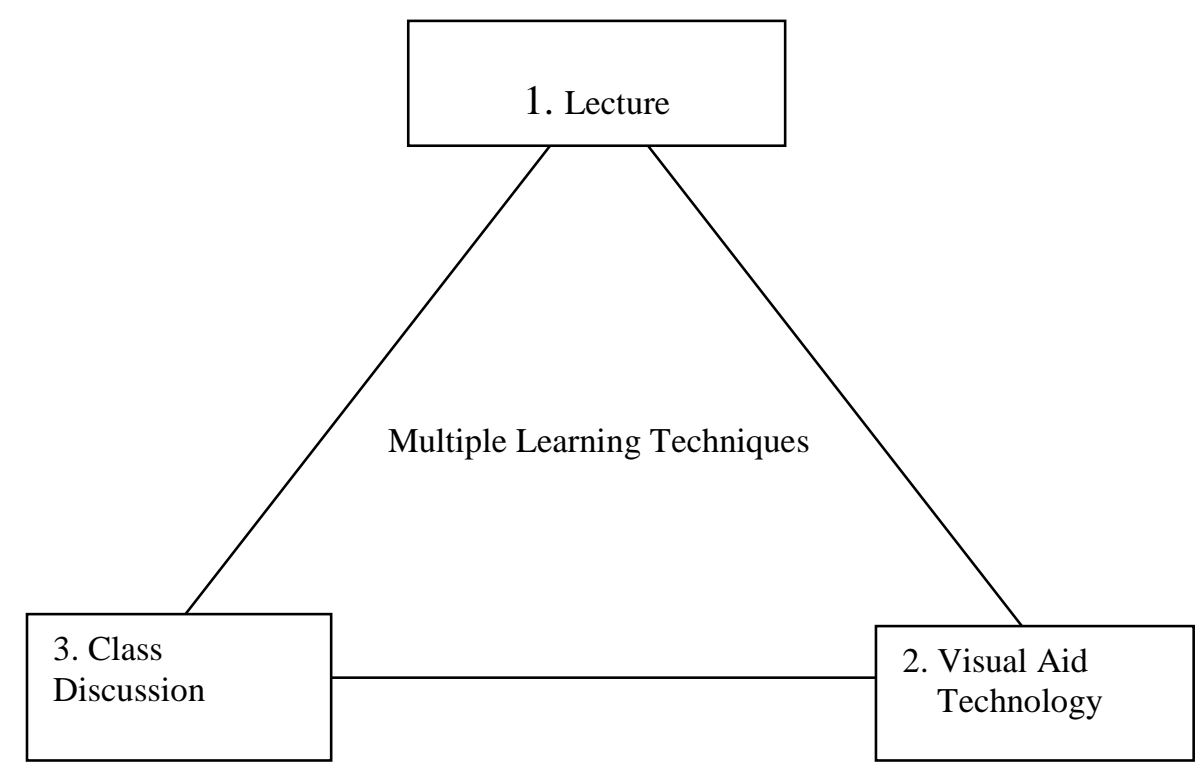

\section{EXTRAORDINARY FACILITATION TO INCREASE LEARNING}

The ultimate goal of affective teaching philosophy is to provide students with an effective learning environment. One way of doing this is to place significant emphasis on the theory to business practitioner relevancy. Education of adults should continually seek and acknowledge the wealth of experience from students; which is conducted during the discussion phase of classes. All students are treated with respect and are encouraged to discuss their views in class. As professors, the authors encourage students to develop their leadership roles within the classes by conducting presentations, leading classroom discussions, being effective team players, and by having an active role in the topics for the course. Basically, there are four critical elements of learning that must be addressed to ensure that students learn.

- $\quad$ Facilitation of Learning: Setting an appropriate level of teaching with a relevant level of difficulty for each group of students.

- $\quad$ Reinforcement: The use of positive and negative reinforcements.

- $\quad$ Retention: Students must be able to interpret and apply different theories and practical business applications.

- Transference: The ability of the student to apply what they learned in the course to specific business situations.

Such forms of facilitation should increase learning for students thereby decreasing their desire to cheat on the exams and term projects. Extraordinary educators should focus on student learning, reinforcement of learning, retention of concepts, and the transference of these concepts to the work environment.

\section{SUMMARY}

In order for instructors to expect ethical behavior from their students, the instructor must be persistent on facilitating a classroom environment which focuses on student discussion, team based assignments, and critical thinking skills. Furthermore, the instructor must expect students to apply what they study in order to master the concepts of the course. The instructor to student relationship is the primary means of learning today, which culminates the students' entire process of understanding the course material by applying Bloom's Taxonomy of 
Learning of analysis, synthesis, and evaluation in the classroom. Involving students in the learning process might be the best way to increase their interest and learning while hopefully reducing the need for cheating.

\section{REFERENCES}

1. ABC Prime Time, 2004. Caught Cheating in School. Aired on April 29 ${ }^{\text {th }}$ 2004. Hosted by Charlie Gibson.

2. Bloom, B (1956). Taxonomy of educational objectives: The classification of educational goals. New York, N.Y. David McKay Co.

3. Bloom's Taxonomy of Learning, 2004. Retrieved on May 13, 2004 from: www.officeport.com/ edu/blooms.htm,

4. Bolton, M. (1999). The role of coaching in student teams: A just-in-time approach to learning. Journal of Management Education, 23, 233-250.

5. Colbeck, C. L., Campbell, S. E., \& Bjorklund, S. A. (2000). Grouping in the dark: What college students learn from group projects. The Journal of Higher Education, 71, 60-83.

6. Lang, J., \& Dittrich, J. (1982). Information, skill building, and the development of competence: An educational framework for teaching business policy. Academy of Management Review, 7, 269-279.

7. Mujtaba, B. and Preziosi, R. (April 2005). Adult Education in Academia: Recruiting and Retaining Extraordinary Facilitators of learning. ISBN: 0-9767681-2-7. EXPress Printing and Publishing.

8. Mujtaba, B. and Kennedy, W. K., (March 2005). Facilitating through Collaborative Reflections to Accommodate Diverse Learning Styles for Long-Term Retention. Association for Business Simulation and Experiential Learning (ABSEL) Conference Proceedings.

9. Mujtaba, B. and Kennedy, J. W. (January 2005). Affective Teaching and Facilitation: Increase Learning, Enforce Ethical Standards, and Reduce Dishonesty in the College Classroom. Proceedings of College Teaching and Learning Conference.

10. Shaohua, C, M., \& Gnyawali, D, R. (2003). Developing synergistic knowledge in student groups. The Journal of Higher Education, 74, 689-711. 